\title{
Levotiroksin Sodyum İntoksikasyonu: Olgu Sunumu
}

Levotiroxine Sodium Intoxication: A Case Report Şenay Güven Baysal ${ }^{1}$, Nurcan Bulur ${ }^{1}$

1 Çocuk Sağlığı ve Hastalıkları Bölümü, Uşak Üniversitesi Eğitim ve Araştırma Hastanesi, Uşak/Türkiye

\section{özeT}

Tiroid hormon replasman tedavisinde kullanılan ilaçların başında levotiroksin gelmektedir. Levotiroksin maruziyeti çok farklı klinik bulgularla seyredebilir. Olgumuzda çok miktarda levotiroksin almış 4 yaşında erkek hastayı sunduk. Levotiroksin intoksikasyonu tanısı öykü, fizik muayene ve laboratuvar bulguları ile konulur. Uygun tedavi protokolleri tam olarak netleşmemiştir. Olgumuz yüksek doz levotiroksin almasına rağmen uygun tedavi ile tirotoksikoz belirtileri gelişmeden takip edilerek ve kontrolleri planlanarak taburcu edilmiştir..

Anahtar Kelimeler: Levotiroksin sodyum, intoksikasyon, kolestiramin

\section{ABSTRACT}

Levothyroxine is the leading drug in thyroid hormone replacement therapy. Levothyroxine exposure has very different presentations. We present a 4-year-old boy patient who received too much levothyroxine. Levothyroxine intoxication is diagnosed by history, physical examination and laboratory findings. Appropriate treatment protocols have not been fully clarified. Despite the high dose of levothyroxine in our case, the appropriate treatment with thyrotoxicosis was followed and the controls were planned and discharged.

Key words: Levothyroxine sodium, intoxication, cholestyramine

\section{GiRiş}

Levotiroksin hipotiroidizm tedavisinde en sık kullanılan ilaçtır. Levotiroksinin tedavi dozları yaşa bağlı olarak günde 2 ila $15 \mu \mathrm{g} / \mathrm{kg}$ arasında değişmektedir.(1) Çocuklarda Levotiroksinin aşırı doz alımı genellikle asemptomatiktir. Semptomatik olan hastalarda tirotoksikozise bağlı olarak; disritmiler, miyokart enfarktüsü, hemiparezi, hipertermi ,solunum yetmezliği ve koma gibi ağır durumlar görülebilir (2). Bu olgu sunumunda yüksek doz levotiroksin alan bir çocuk vakayı sunduk.

\section{OLGU}

Dört yaşında erkek çocuk hasta, hipotiroidizm nedeniyle 50 mcg levotiroksin günde 1 tablet replasman tedavisi almaktaydı. 2 yıldır kullanmış olduğu 50 mcg levotiroksin tabletlerinden 75 adet (3.75 mg) almıştı. Evde annesi tarafından boş ilaç kutularının fark edilmesi üzerine tespit edildi. Annesi ilacı kendi verdiği için aldığı tablet miktarından emindi. Başka herhangi bir ilaç alım ve kronik hastalık öyküsü yoktu. Soy geçmişinde özellik yoktu. İlacı aldıktan yaklaşık 1 saat içerisinde ailesi tarafından bilinci açık bir şekilde acil servise getirildi ve gastrik lavaj ile aktif kömür uygulandı. Acil servise başvuru anında hastanın genel durumu iyi, bilinci açık ve koopere-oryante idi. Hasta huzursuz ve terlemesi mevcuttu. Hastanın fizik muayenesinde vücut ağırlığı: $18 \mathrm{~kg}$, boy: $101 \mathrm{~cm}$, arteriyel kan basıncı: 90/50 mmHg, nabız: 120 /dakika ve ateş: $36.6 \mathrm{C}$ ve solunum sayısı $26 / d k$. ve düzenli ve oksijen satürasyonu \%99 olarak tespit edilmişti. Çekilen elektrokardiyografisi (EKG) sinüs taşikardisi ile uyumlu idi ve ilerleyen saatlerde taşikardisi geriledi. Zehir danışma merkezi ile de görüşülerek hasta levotiroksin intoksikasyonu tanısı ile yatırıldı ve monitörizasyonu sağlandı. Bakılan ilk laboratuvar tetkiklerinde TSH: 22,123 mIU/L (normal aralık: (0,5- 4,5 mIU/L ), FT4: 2,71 ng/dl(normal aralık: 0,85-1,6 $\mathrm{ng} / \mathrm{dl}$ ), FT3: 4,68 pg/ml (normal aralık: 2,3 $-4,2 \mathrm{pg} / \mathrm{ml}$ ), WBC:12 900 Glukoz:97 mg/dl, BUN:11 mg/dl, kreatinin: 0,48 mg/dl, ALT: 15 U/L, AST: 28 U/L, CK: 164 U/L, CK-MB: 39 U/L, Troponin: $<0,006 \mathrm{mcg} / \mathrm{L}$ idi. Hastaya kolestiramin tedavisi başlandı. İntravenöz yoldan mayi replasmanı başlandı. Takiplerinde 24 saat sonra bakılan tetkiklerinde TSH: 1,750 mIU/L , FT4: 3,04 ng/dl ve FT3 6,33 pg/ml idi. Günlük tiroid fonksiyon testlerinin takibi yapıldı. Günlük vital bulgular ve hormon seviyeleri Tablo 1'de verilmiştir. Hasta 6. gününde 14. ve 30. günde kontrol günleri planlanarak taburcu edildi.

Yazışma Adresi/Address for Correspondence: Şenay Güven Baysal, Uşak Üniv. Eğitim ve Araştırma H. Çocuk Sağlığı ve Hastalıkları Bölümü Uşak/Türkiye E-Posta/E-Mail: senay177@yahoo.com || Tel: +902762410000 (6104)

Received/Geliş Tarihi: 8 Tem 2018 || Accepted/Kabul Tarihi: 9 Ağu 2018

Bu Eser Creative Commons Atıf-Gayriticari 4.0 Uluslararası Lisansı Ile Lisanslanmıştır. This work is licensed under a Creative Commons

Attribution-NonCommercial 4.0 International License (CC BY-NC 4.0). 
Tablo 1. Vital bulgular ve hormon seviyeleri

\begin{tabular}{|ccccccc|}
$\begin{array}{c}\text { ilaç } \\
\text { alımı } \\
\text { sonrası } \\
\text { (Gün) }\end{array}$ & $\begin{array}{c}\text { Vücut } \\
\text { Sıcaklığı }\end{array}$ & $\begin{array}{c}\text { Kan } \\
\text { Basıncı } \\
\text { mm Hg }\end{array}$ & $\begin{array}{c}\text { Kalp } \\
\text { Atışı } \\
\text { Atış/dk. }\end{array}$ & $\begin{array}{c}\text { TSH } \\
\text { mIU/La }\end{array}$ & $\begin{array}{c}\text { Serbest } \\
\text { T4 } \\
\text { ng/dLb }\end{array}$ & $\begin{array}{c}\text { Serbest } \\
\text { T3 } \\
\text { pg/mlc }\end{array}$ \\
$\mathbf{1}$ & 36,6 & $90 / 50$ & 120 & 22,12 & 2,05 & 4,68 \\
$\mathbf{2}$ & 36,4 & $90 / 60$ & 92 & 1,75 & 3,04 & 6,33 \\
$\mathbf{3}$ & 36,4 & $90 / 60$ & 90 & 0,72 & 2,40 & 6,31 \\
$\mathbf{4}$ & 36,8 & $90 / 60$ & 92 & 0,59 & 1,93 & 5,85 \\
$\mathbf{5}$ & 36,2 & $90 / 60$ & 102 & 0,45 & 1,93 & 5,00 \\
$\mathbf{6}$ & 36,5 & $90 / 60$ & 100 & 0,40 & 1,68 & 4,35 \\
\hline
\end{tabular}

a Normal aralık 0,5-4,5 mIU/L || b Normal aralık 0,8-1,6 ng/dL || c Normal aralık 2,3-4,2 pg/ml

\section{TARTIŞMA}

Levotiroksin tiroid hormon replasman tedavisinde en sık kullanılan ajandır. Çocuklarda levotiroksinin aşırı doz alımı genellikle benign bir seyir izler. (3) İlk değerlendirmede klinik bulgular asemptomatik olmasına rağmen saatler veya günler sonra klinik bulgular oluşabilir.(4) Birçok pediatrik levotiroksin alımı ile ilgili çoğu olguda ya semptom gelişmemiş ya da sadece minimal semptomlar görülmüştür.(5) Çocuklar asemptomatik olabilir veya ateş, taşikardi, hipertansiyon, tremor, uykusuzluk, sinirlilik ve konvülziyon gibi klinik bulgular da gelişebilir (3)

Nadir de olsa bazı vakalarda koma, konvülziyon, akut psikoz ve miyokardiyal enfarktüs bildirilmiştir (6). Alınan levotiroksin miktarı ile semptomların başlangıcı ve ciddiyeti ile her iki triiodotironin (T3) ve tiroksin (T4) serum konsantrasyonları arasında bir korelasyon olmadığı da belgelenmiştir. Semptomların başlaması 6-11 güne kadar gecikebilir. Litovizt'in yaptığı çalışmada 12 yaş altı 78 çocuktan sadece 4'ünde semptom geliştiğini belirtmiş ve bu semptomlara yönelik tedavi düzenlenmiştir ve ilk 1 haftada bulguların gelişebileceğini vurgulamıştır.(5) Semptomlar T4, T3'e dönüştükçe oluşur. T4'ün T3'e çevrimi 48-72 saat boyunca sürer. Levotiroksin aşırı alınımına bağlı akut intoksikasyon daha çok çocuklarda bildirilmiştir. Çocuklarda T3 ve T4 seviyeleri erişkinlerdeki toksikasyon dozlarından genellikle daha yüksek olmasına rağmen ciddi semptom gelişme riski daha azdır (7). Çoğunlukla $3 \mathrm{mg}$ altındaki levotiroksinin akut alımı genç erişkinlerde veya çocuklarda semptomlara neden olmaz. Levotiroksin intoksikasyonunda belirlenmiş bir tedavi protokolü yoktur. Ancak antitiroid ilaçlar, steroidler, beta blokörler, gastrointestinal sistemden emilimi engelleyici ajanlar (aktif kömür) ve kolestiramin tedavide kullanabilecek seçeneklerdir. Olgumuzda kolestiramin tedavisi uyguladık. Kolestiramin tiroksine bağlanarak eliminasyonunu artırır ve sistemik absorbsiyonunu azaltır [8,9]. Çoğunlukla klinik bulguların günler sonra ortaya çıkabilmesinden dolayı hastanın erken dönemde monitörize edilmesi takip açısından önemlidir. Sonuç olarak levotiroksin intoksikasyonu, genellikle ilk birkaç gün asemptomatik seyretmesi ve etkilerinin daha sonra ortaya çıkması nedeni ile mutlaka hastanede yatarak takip edilmelidir. Hastalar tiroid hormonunun yarılanma ömrü göz önünde bulundurularak ortalama 1 hafta kadar takip edilmelidir.

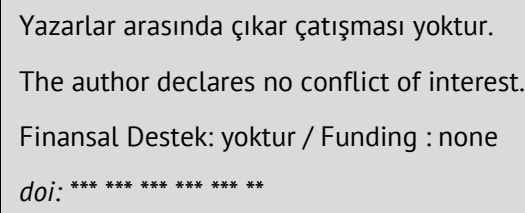

\section{KAYNAKLAR}

1. Pediatric Lexi-Drugs ONLINE. Hudson $(\mathrm{OH})$ : American Pharmaceutical Association; 2010.

2. Luis D.A, Duenas A, Martin J, Abad L, Cuellara L, Aller R. Light Symptoms following a High-Dose Intentional LThyroxine Ingestion Treated with Cholestyramine. Horm Res 2002; 57: 6163.

3. Ho J, Jackson R, Johnson D. Massive levothyroxine ingestion in a pediatric patient: case report and discussion. CJEM. 2011;13(3):165-8.

4. Nystrom $E$, Lindstedt $G$, Lundberg $P$ : Minor signs and symptoms of toxicity in a young woman in spite of massive thyroxine ingestion. ActaMed Scand 1980;207:135-136

5. Litovitz TL, White JD. Levothyroxine ingestion in children: an analysis of 78 cases. Am J Emerg Med. 1985;3(4):297-300

6. Hiassa Y, Ishida T, Aihara T, et al. Acute myocardial infarction due to coronary spasm associated with Lthyroxine therapy. Clin Cardiol 1989; 12: 161

7. Lewander WJ, Lacouture PG, Silva JE, Lovejoy FH. Acute thyroxine ingestion in pediatric patients. Pediatrics 1989; 84: 262.

8. Lehrner LM, Weir MR. Acute ingestions of thyroid hor $\neg$ mones. Pediatrics 1984;73:313-317.

9. Shilo L, Kovatz S, Hadari R, et al. Massive thyroid hor $\neg$ mone overdose: kinetics, clinical manifestations and man-agement. Isr Med Assoc J 2002;4:298-299 